\title{
DAMPAK DEPRESIASI RUPIAH TERHADAP DAYA SAING DAN TINGKAT PROTEKSI KOMODITAS PADI DI KABUPATEN BADUNG
}

\author{
Jarek Putradi \\ Dinas Pertanian, Perkebunan dan Kehutanan Kabupaten Badung, Bali \\ jarek.putradi@gmail.com
}

\begin{abstract}
Fulfilling the food stock became as one of the strategic role agriculture Being the most important part as motors local economy. As illustrated the demand for rice in Badung regency which has population 602.700 , and rate of rice consumption $91,88 \mathrm{~kg}$ percapitalyear is $55.376,08$ ton/year The future policy of national development in the agricultural sector is faced with a change of political order and the globalization challange. The aim of this study is to determine the competitiveness of paddy in terms of the cost of domestic resources, analyzed the government's policy regarding the protection to the producers, and other policies related to improving the competitiveness of the comodities in order to achieve food self-sufficiency in Badung regency. Data was collected by proporsional random sampling and Policy Analysis Matrix=PAM was developed for further analysis. The result showed that farmer's activity in Badung still have competitive in financial and comparative advantage. However, the incorporation effect of policy transfer showing that both farmers and comodity system encounter $24 \%$ of declining protection. Financial and economic competitive was susceptive to exchance rate, price of output, subsidy of input and declining of prodcutivity. The output policy from anticipate depreciation of rupiah still not prosper to farmers. output subsidy that is equivalent to the it shadow price urged to do. Keywords: Depreciation, competitive, protection, paddy, Badung regency.
\end{abstract}

\begin{abstract}
ABSTRAK
Upaya pemenuhan kebutuhan pangan sebagai salah satu peran strategis pertanian merupakan bagian terpenting sebagai penggerak ekonomi daerah. Dapat dilihat dari kebutuhan beras di kabupaten Badung dengan jumlah pennduduk 602.700 jiwa dan tingkat konsumsi beras $91,88 \mathrm{~kg} / \mathrm{kapita} / \mathrm{tahun}$ adalah $55.376,08$ ton beras/tahun. Kebijakan pembangunan nasional sektor pertanian di masa datang dihadapkan pada perubahan tatanan politik di Indonesia dan tantangan globalisasi pada tatanan dunia. Penelitian ini bertujuan untuk mengetahui daya saing komoditas padi dilihat dari biaya sumber daya domestik, dan menganalisis kebijakan pemerintah berkenaan dengan proteksi kepada produsen komoditas padi serta menganalisis kebijakan-kebijakan lain berkaitan dengan peningkatan daya saing komoditas padi dalam mendukung swasembada pangan nasional di Kabupaten Bandung. Pemilihan sampel dilakukan secara proporsional random sampling, dan analisis data dilakukan dengan menggunakan matriks analisis kebijakan (Policy Analysis Matriks+PAM). Hasil analisis menunjukkan bahwa usaha tani padi sawah di Kabupaten Badung masih memiliki daya saing baik secara finansial (keunggulan kompetitif) maupun secara ekonomi (keunggulan komparatif). Namun dampak gabungan policy transfer dari input dan output tradeable menunjukkan bahwa baik petani maupun sistem komoditas mengalami disproteksi sebesar $24 \%$ daya saing secara finansial dan ekonomi ditemukan peka terhadap nilai tukar, harga output, subsidi output dan penurunan produktivitas. Kebijakan output sebagai dampak depresiasi rupiah saat ini ternyata masih belum mensejahterakan petani, maka kebijakan yang mendesak dan berpihak kepada petani dan konsumen adalah meningkatkan subsidi output yang setara dengan harga bayangannya.
\end{abstract}

Kata Kunci: Depresiasi Rupiah, Daya Saing, Tingkat Proteksi, Komoditas Padi, Kabupaten Badung. 


\section{PENDAHULUAN}

Hingga abad ke-21 ini, pembangunan pertanian tetap memegang peran yang strategis dalam perekonomian nasional. Hal tersebut tercermin pada rencana strategis (Renstra) Kementerian Pertanian Republik Indonesia (Kementan RI) 2015-2019 yang memaparkan beberapa fokus penguatan dan pengembangan pertanian Indonesia. Peran strategis tersebut digambarkan melalui kontribusi yang nyata seperti pembentukan kapital, penyediaan bahan pangan, bahan baku industri, pakan dan bio-energi, penyerap tenaga kerja, sumber devisa negara, dan sumber pendapatan, serta pelestarian lingkungan melalui pratek usaha tani yang ramah lingkungan (Kementan, 2015).

Ternyata upaya pemenuhan kebutuhan pangan sebagai salah satu peran strategis pertanian di atas merupakan tugas yang tidak ringan, mengingat jumlah penduduk Indonesia yang besar yaitu 252.164.836 jiwa pada Tahun 2014, dengan tingkat konsumsi beras nasional sebesar 134,64 $\mathrm{kg} /$ kapita/tahun, itu berarti Indonesia membutuhkan beras sebesar 33,95 juta ton. Namun dengan laju pertumbuhan penduduk sebesar 1,49 persen per tahun, maka jumlah penduduk Indonesia tahun 2015 diperkirakan menjadi 255.461 .700 jiwa. Walaupun tingkat konsumsi beras Indonesia mengalami penurunan rata-rata sebesar 1,62 persen per tahun, tentunya masih membutuhkan konsumsi beras yang tinggi seiring dengan meningkatnya jumlah penduduk (Kompas, 2011; 2012, BPS, 2014 dan Kementerian Pertanian RI, 2014).

Sedangkan di Kabupaten Badung hingga Tahun 2014 luas sawah yang masih tersisa adalah 9.984,00 ha, dengan indeks pertanaman sekitar 180,67 persen maka luas panen padi sawah yang terrealisasi adalah sebesar 17.289,23 hektar atau 12,12 persen dari total luas panen padi sawah di Provinsi Bali, yaitu seluas 142.697,00 hektar. Sedangkan rata-rata produktivitas yang dicapai adalah 6,29 ton/ha sehingga produksi padi mencapai 108.758,92 ton gabah kering panen. Dengan potensi ini Kabupaten Badung menyumbang 12,68 persen produksi padi daerah Bali dengan volume 857.944 ton gabah kering panen. Produksi gabah/padi tersebut setara dengan 64.064,91 ton beras, sedangkan kebutuhan beras di Kabupaten Badung dengan jumlah penduduk 602.700 jiwa dan tingkat konsumsi beras Kabupaten Badung 91,88 $\mathrm{kg} / \mathrm{kapita} / \mathrm{tahun}$ adalah 55.376,08 ton beras/tahun, sehingga masih ada surplus beras mencapai $8.688,83$ ton. Kebutuhan beras tersebut belum termasuk untuk industri sebesar 38,44 ton, rumah makan/restoran sebesar 9.938,00 ton dan cadangan konsumsi penduduk sebesar $6.406,49$ ton. Apabila ketiga aspek di atas diperhitungkan, maka Kabupaten Badung menjadi defisit (kekurangan) beras sebanyak 7.694,10 ton (Dinas Pertanian, Perkebunan dan Kehutanan Kabupaten Badung, 2014; dan BPS, 2015).

Pada sisi lain, berbagai aktivitas ekonomi di luar sektor pertanian mulai 
memasuki wilayah-wilayah strategis pertanian sehingga menyebabkan lahanlahan pertanian dengan potensi subur mulai terdegradasi. Penyusutan lahan atau alih fungsi lahanpun tidak terhindarkan, baik itu penyusutan lahan pertanian pada umumnya maupun pertanian sawah pada khususnya.

Selain itu kebijakan pembangunan nasional sektor pertanian saat ini juga dihadapkan pada perubahan tatanan politik di Indonesia yang mengarah pada era demokratisasi serta perubahan tatanan dunia yang mengarah pada globalisasi. Dengan demikian tantangan internal di sektor pertanian tidak saja dituntut untuk mengatasi masalah-masalah yang sudah ada, namun dihadapkan pula pada tuntutan demokratisasi yang terjadi di Indonesia seperti pemberdayaan wilayah dan pemberdayaan petani. Sedangkan tantangan eksternal sektor pertanian karena tuntutan globalisasi terutama untuk negara berkembang diantaranya adalah globalisasi agribisnis, liberalisasi informasi, liberalisasi perdagangan, globalisasi nilai sosial dan lingkungan, perubahan selera konsumen dan perubahan teknologi (Timmer et al., 1983).

Kedua tantangan baik internal maupun eksternal sektor pertanian tersebut membawa implikasi bahwa produk-produk hasil pertanian agar mampu bersaing di pasar internasional harus memenuhi persyaratan wajib (necessary condition), yakni: dihasilkan dengan biaya rendah, memberikan nilai tambah tinggi, mempunyai kualitas tinggi, mempunyai keragaman untuk berbagai segmen pasar, mampu mensubstitusi produk sejenis (impor). Dalam rangka menciptakan struktur agribisnis yang tangguh, maka agribisnis yang terdiri dari subsistem sarana produksi, usahatani, agroindustri, dan pemasaran (pemasaran dalam era liberalisasi perdagangan) haruslah dipadukan dalam keutuhan sistem. Oleh karena itu efisiensi dalam segala subsistem harus dilakukan.

Sementara itu melemahnya nilai tukar Rupiah terhadap Dollar Amerika Serikat yang terjadi cukup lama ternyata secara psikologi juga berimbas pada harga benih, pestisida dan obat-obatan pertanian lainnya, dengan demikian harga benih (padi, palawija dan sayuran), pestisida dan obatobatan pertanian lainnya akan semakin mahal sehingga usaha pertanian yang dilakukan petani menjadi berskala kecil dan sesuai potensi yang ada di desa. Kondisi demikian akan berpengaruh kepada posisi nilai tukar perdagangan (term of trade) komoditas pertanian di era perdagangan bebas.

Berdasarkan kondisi tersebut, Kementerian Pertanian selama lima tahun ke depan, menyusun strategi program peningkatan produksi tanaman pangan dengan menempatkan komoditas padi sebagai salah satu komoditas pangan utama. Fokus peningkatan produktivitas padi tersebut melalui Gerakan Penerapan Pengelolaan Tanaman Terpadu (GPPTT) Padi. Disamping itu untuk mendukung program peningkatan produksi tanaman pangan, khususnya dalam pencapaian swasembada pangan nasional, pemerintah 
memberikan subsidi benih, pupuk, perbaikan prasarana dan sarana pertanian, pengembangan teknologi berbasis sumberdaya spesifik lokasi (kearifan lokal) dan sesuai agroekosistem setempat dengan teknologi unggul yang berorientasi kebutuhan petani, dan penetapan Harga Pembelian Pemerintah (HPP) untuk gabah yang berpihak kepada petani (Zaini, 2009; Kardinan, 2011).

Untuk lebih mendorong peningkatan produksi dan pendapatan petani dalam situasi sulit seperti di atas, berbagai upaya telah dilakukan Pemerintah Daerah Kabupaten Badung antara lain dengan memberikan subsidi ganda pupuk organik dan NPK Phonska. Dengan tersedianya fasilitas di atas diharapkan dapat meningkatkan usahataninya sehingga dapat meningkatkan pendapatan dan kesejahteraan petani.

Apakah kebijakan insentif yang telah diberikan pemerintah dari sudut ekonomi dapat mendorong usahatani padi terutama terhadap beberapa hal diantaranya: Apakah usaha tani padi sawah di Kabupaten Badung masih mempunyai daya saing baik berdasarkan keunggulan kompetitif maupun keunggulan komparatif dilihat dari biaya sumberdaya domestik (domestic resource $\operatorname{cost}$ )? Apakah kebijakan pemerintah saat ini telah memberikan proteksi kepada petani produsen padi? dan apakah diperlukan kebijakan-kebijakan lain dalam rangka meningkatkan daya saing komoditas padi dalam mendukung swasembada pangan nasional?, menjadi permasalahan yang akan dicari solusinya dari tulisan ini

Dari penelitian ini diharapkan akan dapat dianalisis daya saing (keunggulan kompetitif dan komparatif) komoditas padi sawah dilihat dari biaya sumberdaya domestik di Kabupaten Badung, kebijakan pemerintah berkenaan dengan proteksi kepada produsen komoditas padi di Kabupaten Badung dan kebijakan-kebijakan lain dalam rangka meningkatkan daya saing komoditas padi dalam mendukung swasembada pangan nasional.

\section{TINJAUAN PUSTAKA}

Bagi Indonesia dan juga masyarakat Kabupaten Badung, padi/beras merupakan komoditas yang memiliki nilai strategis, baik dari segi ekonomi, lingkungan hidup, sosial maupun politik. Demikian strategisnya isu perberasan senantiasa menjadi perhatian pemerintah, khususnya menyangkut kebijakan perdagangan internasional, distribusi, pemasaran dan harga domestik. Apalagi perdagangan beras secara internasional sangat sensitif terhadap perubahan harga beras di pasaran dunia dan perubahan nilai tukar. Mengingat karakteristik produksi dan pemasaran komoditas beras tergolong unik dan tidak sama dengan produk-produk industri dan jasa, menyebabkan banyak negara di Asia, seperti Bangladesh, Philipina dan Pakistan menerapkan langkah perlindungan terhadap petani produsennya (Sudaryanto dan Rachman, 2000). Oleh karenanya, berbagai kalangan menganggap bahwa kebijakan 
fasilitas dan perlindungan pemerintah bagi petani produsen padi/beras domestik dinilai masih relevan.

Apalagi kondisi sistem produksi pertanian di Indonesia yang umumnya masih dicirikan: (1) skala usaha kecil dan penggunaan modal kecil; (2) penerapan teknologi usahatani belum optimal; (3) belum adanya sistem pewilayahan komoditas yang memenuhi azas-azas pengembangan usaha agribisnis; penataan produksi belum berdasarkan keseimbangan antara supply dan demand; dan (5) sistem panen dan penanganan pascapanen yang belum prima; serta (6) sistem pemasaran hasil belum efisien dan harga lebih banyak ditentukan oleh pedagang. Akibat dari sistem produksi tersebut, maka produktivitas dan kualitas hasil belum dapat tercapai, produksi bersifat musiman, harga tidak stabil, dan keamanan pangan produk kurang terjamin. Konsekuensi dari kondisi tersebut adalah komoditas atau produk pertanian meskipun mempunyai keunggulan komparatif namun sulit diwujudkan menjadi keunggulan kompetitif terutama jika tujuan pasarnya adalah ekspor, sedangkan pasar domestikpun kebanjiran produk-produk pertanian dari luar negeri, seperti pada kasus beras, jagung, kedelai, dan buah-buahan, serta susu (Saptana, 2009).

\section{METODE PENELITIAN}

\section{Lokasi dan Waktu Penelitian}

Penelitian ini merupakan studi kasus pada sistim komoditas padi di Kabupaten
Badung, Provinsi Bali. Penentuan lokasi penelitian ini dilakukan secara purposive sampling, yaitu penentuan lokasi penelitian yang dilakukan secara sengaja dengan beberapa pertimbangan sebagai berikut.

a. Kabupaten Badung merupakan salah satu sentra produksi tanaman padi sawah di Bali setelah Kabupaten Tabanan, Gianyar dan Buleleng yang memiliki keadaan tanah dan iklim yang cocok untuk pertumbuhan tanaman padi sawah.

b Merupakan daerah yang tetap melaksanakan program Peningkatan Ketahanan Pangan, program Pengembangan Agribisnis, dan program Peningkatan Kesejahteraan Petani.

c Pemerintah daerah Kabupaten Badung sampai saat ini masih memberikan perhatian yang besar pada komoditas padi sawah, dengan direalisasikannya beberapa program pertanian berkenaan dengan upaya peningkatan daya saing usahatani padi sawah serta pemberdayaan petani padi.

d Pada Tahun 2014, rata-rata produktivitas padi di Kabupaten Badung cukup tinggi sebesar $62,90 \mathrm{ku} / \mathrm{ha}$, di atas rata-rata produktivitas padi Provinsi Bali sebesar 60,12 ku/ha.

Penelitian lapangan pada usahatani padi sawah untuk memperoleh data dan informasi tentang biaya dan penerimaan sampai dengan impor pada masa tanam 2014/2015 dilakukan lebih kurang satu bulan, yaitu pada minggu kedua bulan Maret hingga minggu kedua bulan April 2015. 


\section{Penentuan Populasi dan Sampel}

Populasi atau keseluruhan objek pengamatan dalam penelitian ini adalah ketua-ketua kelompok tani atau pekasehpekaseh yang terhimpun dalam Subak di Kabupaten Badung. Berdasarkan data Dinas Pertanian, Perkebunan dan Kehutanan Kabupaten Badung, bahwa Kabupaten Badung memiliki 119 Subak/Kelompok Tani yang tersebar di 6 (enam) Kecamatan.

Penentuan sampel dalam penelitian ini adalah ketua - ketua subak / kelompok tani (pekaseh) yang dipilih secara proporsional random sampling, sebanyak $28 \%$ atau 33 sampel dengan asumsi bahwa jumlah populasi yang ada relatif homogen dilihat dari aspek usahataninya.

\section{Jenis dan Sumber Data}

Jenis data yang dikumpulkan dalam penelitian ini meliputi, (a) data kuantitatif, yakni data yang diukur dengan suatu alat ukur tertentu dan berbentuk angka-angka seperti input fisik, biaya-biaya produksi, produksi, harga output, penerimaan, keuntungan, biaya distribusi, kurs dolar terhadap rupiah dan informasi impor (b) data kualitatif, yakni data yang tidak berbentuk angka-angka tetapi berupa penjelasan yang berhubungan dengan objek penelitian, seperti kualitas komoditas beras diasumsikan sama dengan kualitas beras pecah $5 \%$ Vietnam.

Sumber-sumber data penelitian yaitu (1) data primer adalah data yang bersumber dari petani padi sawah sebagai responden penelitian; dan (2) data sekunder adalah data yang bersumber dari pihak kedua seperti
Badan Pusat Statistik (BPS), Kementerian Pertanian, Bank Indonesia (BI), Dinas Pertanian Tanaman Pangan Provinsi Bali, Dinas Pertanian Perkebunan dan Kehutanan Kabupaten Badung, serta lembaga lainnya yang berkaitan dengan penelitian.

\section{Teknik Pengumpulan Data}

Penelitian ini menggunakan metode survei yang mengambil responden dari satu populasi dan menggunakan kuesioner sebagai alat pengumpul data pokok untuk mewakili seluruh populasi yang ada.

Data dikumpulkan melalui tiga cara yaitu (1) wawancara langsung kepada responden dengan menggunakan kuesioner terstruktur yang telah disiapkan, observasi yaitu metode pengumpulan data dengan cara melakukan pengamatan langsung ke lapangan dan (3) Studi kepustakaan, yaitu metode pengumpulan data dengan mencatat informasi yang relevan dari buku-buku, laporan-laporan, jurnal ilmiah, majalah dan media sosial.

\section{Variabel Penelitian}

Penelitian ini terdiri atas beberapa variabel yang pengumpulan datanya terdiri dari dua jenis data yaitu data primer dan sekunder. Variabel data primer meliputi: (1) Struktur input (tradable inputs dan faktor domestik) dan output fisik per hektar. (2) Harga privat input yang diperdagangkan dan faktor domestik, serta harga output di tingkat petani.

Variabel dari data sekunder adalah: (1) Perkembangan luas areal, produksi, produktivitas, konsumsi, ekspor dan impor 
komoditas beras di Kabupaten Badung, Provinsi Bali, dan Indonesia. (2) Perkembangan produksi, konsumsi dan harga beras dunia. (3) Perkembangan ekspor dan impor komoditas beras dunia. (4) Budidaya padi sawah, pengolahan gabah dan pemasaran beras. (5) Perkembangan nilai tukar dolar US terhadap rupiah. (6) Nilai pemilahan kandungan komponen input. (7) Faktor konversi harga pasar aktual (privat) ke harga bayangan (sosial).

Perkembangan harga dasar dan harga impor pupuk kimia.

\section{Batasan Operasional Variabel/Istilah}

Agar penelitian ini tidak menyimpang dari pokok permasalahan, maka dalam penelitian ini diberikan batasan-batasan. Batasan operasional yang digunakan dalam penelitian ini, sebagai di bawah ini.

(1) Harga pasar adalah harga yang benarbenar diterima petani atau produsen dan di dalamnya terdapat kebijakan pemerintah.

(2) Harga bayangan adalah harga pada pasar persaingan sempurna yang mewakili biaya imbangan sosial yang sesungguhnya. Pada komoditas tradable, harga bayangan adalah harga yang terjadi di pasar internasional.

(3) Input tradable adalah input produksi yang dapat diperdagangkan secara internasional (seperti pupuk kimia, benih, alat produksi, obat-obatan).

(4) Untuk benih padi penentuan harga sosialnya didekati dari harga aktualnya, namun karena benih padi saat ini masih ada subsidi Rp. 400,00/kg, maka harga sosial adalah harga aktual ditambah besarnya subsidi.

(5) Harga sosial pupuk lain, pestisida, herbisida dan fungisida, bentuk cair maupun padat digunakan harga privat aktual di lokasi penelitian, kemudian dikurangi tarif impor sebesar 10 persen dan pajak pertambahan nilai 7,5 persen.

(6) Harga sosial lahan didekati dengan mencari opportunity cost of landdari komoditas alternatif terbaik (the next best alternative commodity) pada masa tanam 2014/2015. Dalam penelitian ini Harga sosial lahan merupakan keuntungan kotor sebelum dikurangi sewa lahan dari komoditas alternatif terbaik, yaitu kedelai.

(7) Input non tradable atau faktor domestik adalah input produksi yang tidak diperdagangkan di pasar internasional (seperti tenaga kerja, lahan, modal).

(8) Output bersifat tradable, dan input dapat dipisahkan ke dalam input tradable dan faktor domestik (input non tradable).

(9) Output fisik adalah hasil produksi usahatani padi sawah, dalam hal ini adalah hasil gabah kering panen.

(10) Harga privat input adalah harga aktual dari input produksi yang dibayar petani padi sawah. 
(11) Harga faktor domestik adalah harga input non tradable atau faktor domestik yang dibayar oleh petani padi sawah berdasarkan harga yang berlaku di pasar domestik.

(12) Harga sosial tenaga kerja dihitung dengan menggunakan nilai upah aktual yang berlaku di lokasi penelitian. Hal ini didasari pemikiran bahwa aksesibilitas lokasi sentra produksi padi pada umumnya memadai, sehingga mendorong berjalannya pasar tenaga kerja di pedesaan dan terintegrasinya pasar tenaga kerja, baik antar wilayah maupun antar sektor.

(13) Harga sosial traktor dan power thresher akan dihitung dengan menggunakan nilai sewa aktual yang berlaku di lokasi penelitian. Hal ini didasari pemikiran bahwa pasar jasa alsintan (traktor dan power thresher) di lokasi kajian sudah berjalan cukup baik dan mampu menggambarkan kondisi pasar persaingan sempurna.

(14) Harga bayangan peralatan (sabit, cangkul, dll) diproksi dari nilai penyusutan aktual per musim.

(15) Sebagian besar petani padi akses terhadap perbankan baik bank pemerintah, bank swasta, bank asing, bank campuran, bank perkreditan rakyat maupun lembaga keuangan lainnya, sehingga tingkat suku bunga dalam penelitian ini menggunakan tingkat suku bunga yang dikeluarkan Bank Indonesia.
(16) Harga sosial modal (tingkat bunga) diklasifikasikan menurut katagori modal kerja (kurang dari satu tahun) dan modal investasi (lebih dari satu tahun). Rule of thumb penentuan harga sosial modal (berdasarkan negara lain yang setara) untuk investasi adalah $10-15$ persen plus inflasi, sedangkan untuk modal kerja $15-20$ persen plus inflasi, sehingga diperoleh harga bayangan bunga modal per musim tanam (empat bulan).

(17) Asumsi makro ekonomi lainya adalah sebagai berikut: (1) rata-rata tingkat suku bunga Bank Indonesia musim tanam 2014/2015 adalah 7,625persen, (2) laju inflasi Tahun 2014 (April 2014-Maret 2015) adalah 6,1142 persen, (3) tingkat suku bunga sosial 21,1142 persen per tahun dan (4) rata rata nilai tukar rupiah terhadap dollar Amerika pada 01 Desember 2014 31 Maret 2015 adalah Rp 12.775,35 per US \$ (Bank Indonesia, 2015).

(18) Komoditas padi diasumsikan mempunyai kualitas yang sama dengan padi yang diproduksi di luar negeri.

(19) Eksternalitas sama dengan nol.

\section{Metode Analisis Data}

Analisis penelitian menggunakan metode PAM (Policy Analysis Matrix), yang dikembangkan oleh Pearson, Gotsch dan Bahri (2005). 


\section{Analisis Sensitivitas}

Untuk memperoleh pemahaman tingkat sensitivitas (kepekaan) usaha tani padi ada beberapa perubahan yang mungkin akan terjadi dalam jangka pendek sehingga perlu dibuatkan simulasi. Adapun perubahan kondisi tersebut adalah sebagai berikut.

(1) Nilai rupiah akan semakin melemah (depresiasi) terhadap dollar Amerika Serikat menjadi Rp 13.500 per US \$ dan nilai rupiah akan menguat (apresiasi) menjadi Rp 11.900,00 per US \$ sesuai asumsi dasar ekonomi makro Tahun 2015.

(2) Meningkatnya subsidi output yang setara dengan harga bayangan, yaitu sebesar Rp 4.949,63/kilogram gabah kering panen.

(3) Adanya subsidi benih padi sebesar Rp 5.500,00/kilogram, benih kedelai sebesar Rp 10.000,00/kilogram, subsidi ganda pupuk NPK Phonska sebesar Rp $8.00,00 / \mathrm{kg}$ dan pupuk organik sebesar Rp 400,00/kg dari kegiatan APBD Kabupaten Badung.

(4) Ada kecenderungan bahwa produktivitas gabah semakin berkurang karena penggunaan benih berkualitas bukan F1 (generasi pertama) tetapi turunannya, dan adanya serangan hebat hama/penyakit. Bila teknologi produksi tidak berkembang, hasil gabah akan berkurang sampai 20 persen. Kasus ini bisa saja dijumpai di beberapa daerah produksi seperti di Kabupaten Badung, yang menyebabkan petani menderita kerugian.

Dalam penelitian ini dianalisis titik impas pada harga ekonomi untuk mengetahui tingginya tingkat keuntungan ekonomi usahatani padi sawah di Kabupaten Badung.

\section{HASIL DAN PEMBAHASAN}

\section{Asumsi Ekonomi Makro}

Asumsi makro ekonomi yang digunakan adalah rata-rata tingkat suku bunga Bank Indonesiadan rata - rata nilai tukar rupiah terhadap dollar US (Rp per US Dollar) selama musim tanam padi dari bulan Desember 2014 sampai dengan bulan Maret 2015.

Tingkat suku bunga sosial (social interest rate) menggunakan pendekatan dari besarnya social opportunity cost of capital Negara di Asia Tenggara yang diasumsikan sebesar $15 \%$ per tahun ditambah dengan laju inflasi nasional pada tahun penelitian. Rata - rata laju inflasi nasional pada tahun 2014 adalah 6,11 persen sehingga tingkat suku bunga sosial berada pada kisaran 21,11 persen per tahun atau 7,04 persen per musim. 
Tabel 1 Asumsi Ekonomi Makro

\begin{tabular}{lr}
\multicolumn{1}{c}{ Asumsi Ekonomi Makro } & Jumlah \\
\hline Tingkat suku bunga Bank Indonesia (persen per musim) & $7,63 \%$ \\
Tingkat suku bunga sosial (persen per tahun) & $21,11 \%$ \\
Tingkat suku bunga sosial (persen per musim) & $7,04 \%$ \\
Nilai tukar rupiah (Rp/\$) & \\
Rata-rata 01 Desember 2014 - 31 Maret 2015 & $12.775,35$ \\
\hline
\end{tabular}

Sumber : Pearson, Gotsch dan Bahri (2005) dan Bank Indonesia (2015).

\section{Analisis Keuntungan Komoditas Padi Sawah di Kabupaten Badung}

Dua aspek keuntungan komoditas padi, yaitu Keuntungan privat (finansial) dan Keuntungan sosial (ekonomi). Dalam analisis keuntungan finansial, maka penerimaan dan biaya (input) didasarkan pada tingkat harga pasar atau harga aktual yang diperoleh dari usahatani maupun pengolahan hasil. Harga tersebut sudah dipengaruhi oleh kebijakan pemerintah, seperti subsidi, bunga modal, proteksi dan bea masuk. Sehingga subsidi, bunga modal, proteksi dan bea masuk merupakan biaya dan keuntungan usaha. Keuntungan finansial diharapkan mempunyai nilai positif dan meningkat dari waktu ke waktu. Sedangkan keuntungan ekonomi dihitung jika terjadi pada pasar persaingan sempurna, dimana tidak ada kegagalan pasar dan campur tangan atau kebijakan pemerintah. Pada analisis keuntungan ekonomi, penerimaan dan biaya (input) didasarkan pada tingkat harga sosial atau harga bayangan (shadow price), maka pajak dan subsidi dianggap sebagai suatu pembayaran aliran sehingga tidak mempengaruhi arus biaya dan penerimaan.
Suatu usahatani yang menguntungkan secara finansial belum tentu menguntungkan secara ekonomi. Hal tersebut dimungkinkan, misalnya karena terdapat subsidi pada input produksi sehingga keuntungan finansial akan meningkat, namun keuntungan ekonomi tetap atau mengalami penurunan. Apabila tidak disertai peningkatan produktivitas dan atau harga output, maka secara ekonomi kebijakan subsidi tersebut tidak akan meningkatkan keuntungan ekonomi.

\section{Analisis keuntungan finansial}

Hasil analisis menunjukkan bahwa keuntungan finansial usahatani padi sawah di Kabupaten Badung adalah sebesar Rp 8.343.248,82 per hektar, dengan nilai $\mathrm{R} / \mathrm{C}$ atau PBCR sebesar 1,47. Dari hasil tersebut dapat dikatakan bahwa petani padi di Kabupaten Badung telah memperoleh keuntungan dalam melaksanakan usahatani padi.

Dapat dikatakan bahwa usahatani padi sawah di Kabupaten Badung secara finansial layak untuk dikembangkan, karena rasio $\mathrm{R} / \mathrm{C}$ atau PBCR lebih besar dari 1. Menurut Pearson, Gotsch dan Bahri (2005) suatu aktivitas ekonomi yang mempunyai keuntungan finansial diatas normal merupakan indikator bahwa pengembangan 
aktivitas ekonomi tersebut masih dimungkinkan. Perhitungan keuntungan sawah di Kabupaten Badung disajikan pada finansial atau kelayakan usahatani padi

Tabel 3.2.

Tabel 2 Keuntungan Finansial Usahatani Padi Sawah di Kabupaten Badung Masa Tanam 2014/2015

\begin{tabular}{lr}
\hline \multicolumn{1}{c}{ Uraian } & $\begin{array}{c}\text { Usahatani Padi } \\
\text { (Rp/Ha) }\end{array}$ \\
\hline Total penerimaan & $25.942 .984,73$ \\
Total biaya & $17.599 .735,92$ \\
Keuntungan finansial & $8.343 .248,82$ \\
PBCR (private benefit-cost & 1,47 \\
ratio) & \\
\hline Sumb
\end{tabular}

Sumber : Data primer.

\section{Analisis keuntungan ekonomi}

Berdasarkan analisis maka keuntungan ekonomi usahatani padi sawah tingkat petani di Kabupaten Badung adalah Rp 11.373.037,50 per hektar per musim tanam. Nilai $\mathrm{R} / \mathrm{C}$ atau SBCR dalam analisis ini sebesar 1,50. Secara umum dapat dikatakan bahwa sistem usahatani padi sawah juga layak secara ekonomi, karena rasio $\mathrm{R} / \mathrm{C}$ atau SBCR lebih besar dari 1. Hasil perhitungan keuntungan ekonomi atau kelayakan usahatani padi sawah secara ekonomi selengkapnya disajikan pada Tabel 3.3

Tabel 3 Keuntungan Ekonomi Usahatani Padi Sawah di Kabupaten Badung Masa Tanam 2014/2015

\begin{tabular}{lr}
\hline \multicolumn{1}{c}{ Uraian } & $\begin{array}{c}\text { Usahatani Padi } \\
\text { (Rp/Ha) }\end{array}$ \\
\hline Total penerimaan & $33.926 .930,74$ \\
Total biaya & $22.553 .893,24$ \\
Keuntungan finansial & $11.373 .037,50$ \\
SBCR (social benefit-cost & 1,50 \\
ratio) & \\
\hline Sut
\end{tabular}

Sumber: Data primer.

Apabila sebuah sistem usahatani komparatif dalam menggunakan menghasilkan keuntungan sosial (ekonomi) sumberdaya ekonomi. yang positif, berarti usahatani tersebut dapat bersaing pada tingkat harga internasional, tanpa bantuan kebijakan pemerintah apapun. Karena keuntungan privat (finansial) dan keuntungan sosial (ekonomi) usahatani padi sawah adalah positif, maka usahatani padi sawah di Kabupaten Badung memiliki keuntungan kompetitif dan keuntungan

\section{Analisis Daya Saing Komoditas Padi Sawah Di Kabupaten Badung}

Daya saing dapat dianalisis melalui nilai rasio pada metode Policy Analysis Matrix (PAM). Ada dua rasio yang digunakan untuk menilai daya saing, yaitu rasio biaya privat (Privat Cost Ratio atau PCR) dan rasio biaya domestik (Domestic Resourse Cost Ratio atau DRC). Nilai PCR 
merupakan ukuran daya saing atau efisiensi pada nilai finansial atau keunggulan kompetitif. Rasio ini dapat digunakan sebagai indikator untuk mencapai tujuan dari kegiatan usahatani yaitu memperoleh keuntungan maksimum. Supaya diperoleh nilai keuntungan maksimum maka petani selalu berusaha meminimumkan nilai PCR, misalnya dengan meminimumkan pengeluaran biaya faktor domestik atau dengan cara memaksimumkan nilai tambah, yaitu dengan cara meminimumkan input tradabel. Itu berarti keunggulan kompetitif akan dicapai jika nilai PCR lebih kecil dari satu $(\mathrm{PCR}<1)$, sebaliknya tidak mempunyai keunggulan kompetitif jika PCR $>1$.
Hasil analisis dengan menggunakan metode Policy Analysis Matrix (PAM) menunjukkan bahwa usahatani padi sawah di Kabupaten Badung merupakan sistem usahatani yang menguntungkan dan memiliki keunggulan kompetitif, karena besarnya rasio biaya privat (PCR) untuk sistem usahatani padi sawah pada masa tanam 2014/2015 adalah 0,66. Itu berarti usahatani padi sawah di atas bisa diusahakan, karena untuk menghasilkan satu unit nilai tambah memerlukan biaya domestik yang lebih kecil dari satu unit. Perhitungan nilai PCR selengkapnya seperti Tabel 3.4 berikut.

Tabel 4 Analisis PCR dan DRC Usahatani Padi Sawah Di Kabupaten Badung Pada Masa Tanam 2014/2015

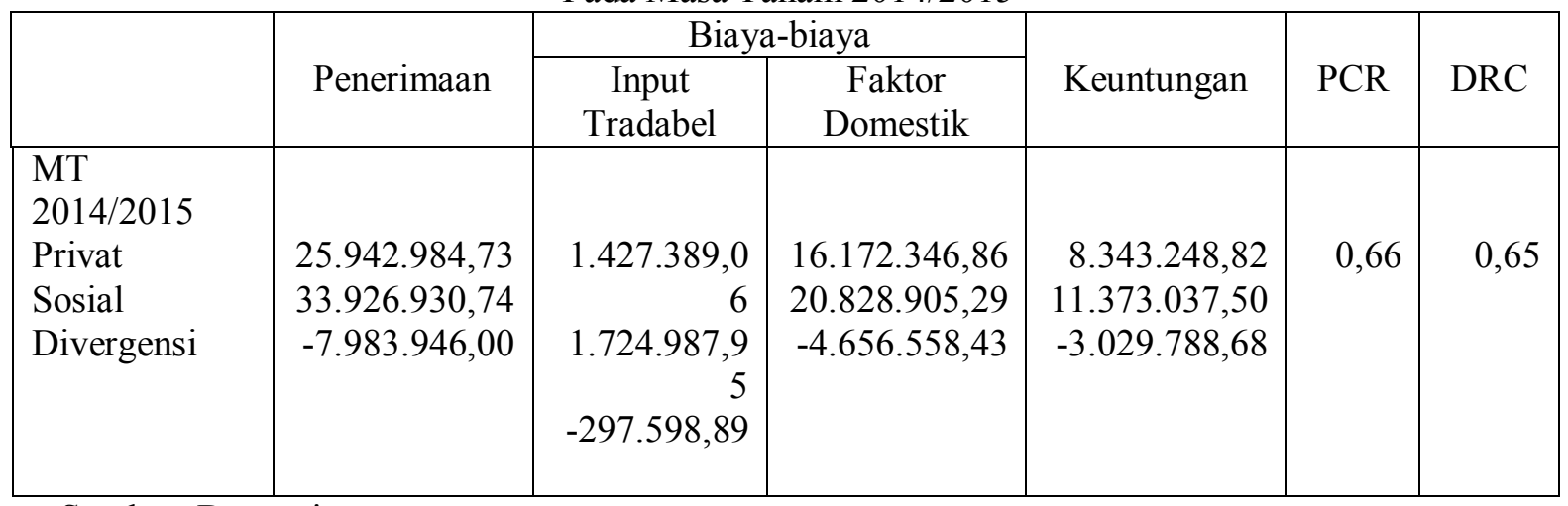

Sumber: Data primer.

Sedangkan nilai DRC merupakan ukuran daya saing secara internasional atau keunggulan komparatif suatu komoditas. Rasio ini untuk menilai suatu aktifitas ekonomi (layak atau tidak layak) ditinjau dari segi pemanfaatan sumberdaya domestik yang digunakan. Usahatani suatu komoditas dikatakan mempunyai daya saing secara internasional jika rasio DRC <
1, artinya komoditas tersebut lebih menguntungkan jika diusahakan di dalam negeri dari pada diimpor. Sebaliknya jika rasio DRC $>1$ berarti usahatani suatu komoditas tidak mempunyai daya saing internasional atau secara ekonomi tidak layak untuk diusahakan karena terjadi pemborosan sumberdaya domestik. Sehingga pada kondisi seperti ini akan 
lebih menguntungkan jika komoditas tersebut diimpor daripada diusahakan di dalam negeri.

Nilai DRC memainkan fungsi yang sama seperti PCR, hanya berbeda dalam dasar penilaian harga. Jika PCR dinilai dalam harga privat (finansial) yang sudah dipengaruhi kebijakan pemerintah, maka DRC dinilai berdasarkan harga sosial (ekonomi). Berdasarkan perhitungan seperti pada Tabel 3.4 di atas, maka nilai rasio sumberdaya domestik atau Domestic Resourse Cost (DRC) usahatani padi sawah pada masa tanam 2014/15 atau musim hujan di Kabupaten Badung adalah 0,65. Nilai-nilai tersebut menunjukkan bahwa untuk mendapatkan 1 unit nilai tambah diperlukan biaya domestik sebesar 0,65 unit pada usahatani padi sawah pada musim hujan. Dalam kaitan perdagangan internasional maka nilai rasio DRC usahatani padi sawah pada musim hujan sebesar 0,65artinya bahwa setiap 1 \$ US devisa negara yang dikeluarkan untuk mengimpor padi, jika diproduksi di dalam negeri hanya dibutuhkan biaya $0,65 \$$ US .

Dari uraian di atas, untuk memenuhi kebutuhan beras nasional yang tiap tahun nilai impornya cukup besar dan untuk menghemat devisa negara dari sektor nonmigas, maka Kabupaten Badung sangat cocok jika dijadikan sebagai salah satu sentra pengembangan usahatani padi nasional.

Salah satu faktor yang menyebabkan komparatifnya suatu sistem usahatani padi sawah di Kabupaten Badung adalah penggunaan input tradable dan domestik yang biayanya cukup tepat. Penggunaan biaya input tradable pada usahatani padi sawah yang sebagian besar berupa pengadaan pupuk anorganik, benih, pestisida dan herbisidadalam jumlah yang tepat dan sesuai dengan paket teknologi anjuran. Disamping itu berkurangnya serangan organisme pengganggu tanaman pada masa tanam 2014/2015 menyebabkan petani menerapkan prinsip pengendalian hama terpadu dan menggunakan sedikit pestisida, berarti petani telah meminimumkan biaya input tradable. Meminimumkan biaya input tradable dalam sistem usahatani padi sawah dapat meminimumkan DRC. Meminimumkan nilai DRC ekivalen dengan memaksimumkan keuntungan ekonomi (sosial).

Dari hasil analisis PCR dan DRC pada usahatani padi sawah di atas menunjukkan bahwa nilai $\mathrm{PCR}<1$ dan $\mathrm{DRC}<1$, dengan demikian usahatani padi sawah di Kabupaten Badung mempunyai keunggulan kompetitif dan keunggulan komparatif. Selain itu juga diketahui bahwa nilai PCR pada usahatani padi sawah mempunyai nilai yang lebih tinggi daripada nilai DRCnya, atau PCR > DRC. Keadaan ini memberi arti bahwa untuk menghasilkan satu unit nilai tambah memerlukan faktor domestik yang lebih besar dibandingkan dengan tanpa adanya kebijakan pemerintah. Dengan kata lain masih diperlukan kebijakan pemerintah untuk menunjang daya saing pada nilai finansial. Kebijakan 
pemerintah yang sesuai untuk meningkatkan daya saing secara finansial adalah meningkatkan harga gabah (subsidi output) di tingkat petani.

\section{Dampak Kebijakan Pemerintah}

\section{Divergensi}

Tabel 3.4 menunjukkan bahwa divergensi dalam penerimaan (revenue) pada usahatani padi sawah di Kabupaten Badung pada masa tanam 2014/2015 atau musim hujan sebesar -Rp 7.983.946,00 per hektar, disebabkan oleh perbedaan harga privat yang diterima petani dengan harga sosialnya. Divergensi usahatani padi sawah ini bernilai negatif, hal ini menunjukkan bahwa konsumen membeli dan produsen (petani) menerima dengan harga yang lebih rendah dari harga seharusnya. Itu berarti kebijakan pemerintah mengenai harga gabah yang tertuang dalan Inpres No. 5 Tahun 2015 berdampak merugikan produsen (petani) atau subsidi output yang diberikan belumdapat meningkatkan kesejahteraan petani.

Sedangkan divergensi input yang diperdagangkan (tradable) pada usahatani padi sawah sebesar - Rp 297.598,89 per hektar disebabkan oleh perbedaan harga privat dengan harga sosialnya. Dari hasil analisis tersebut divergensi input tradabel bernilai negatif artinya terdapat kebijakan yang menghasilkan harga privat yang lebih rendah atau petani sebagai konsumen membayar harga input secara keseluruhan lebih murah daripada harga sosialnya (pasar internasional). Nilai negatif pada divergensi input tradabel menunjukkan adanya kebijakan subsidi. Hal ini berarti bahwa usahatani padi sawah di Kabupaten Badung pada masa tanam 2014/2015 menerima subsidi input. Subsidi input dari pemerintah yang diterima petani pada usahatani padi sawah pada masa tanam 2014/2015 adalah benih, pupuk Urea, pupuk lain, pestisida dan herbisida.

Input faktor domestik adalah input produksi yang harganya ditentukan oleh pasar domestik. Perbedaan harga finansial dan harga ekonomi tidak semata-mata disebabkan oleh kebijakan pajak atau subsidi, tetapi juga adanya unsur perbedaan penilaian pada faktor domestik. Penilaian upah tenaga kerja, biaya kapital pada nilai finansial, penyusutan alat pertanian, pajak lahan dan sewa lahan tidak dimasukkan dalam perhitungan nilai ekonomi. Dari Tabel 3.4 dapat diketahui bahwa divergensi faktor domestik pada usahatani padi sawah menunjukkan nilai negatif, yaitu sebesar Rp 4.656.558,43 per hektar. Nilai divergensi faktor domestik yang negatif menunjukkan adanya perbedaan penilaian yang lebih rendah pada harga finansial, karena tidak berkembangnya sistem sewa lahan.

Divergensi tenaga kerja pada usahatani padi sawah sama dengan nul, karena tidak ada perbedaan biaya tenaga kerja privat (finansial) dan sosial (ekonomi). Sedangkan divergensi pada biaya modal timbul sebagai akibat dari biaya modal (tingkat bunga) sosial lebih rendah dari tingkat bunga privatnya. 
Tingkat bunga privat adalah 7,63\%/musim, sementara tingkat bunga sosial adalah 7,04\%/musim.

Divergensi biaya-biaya lain (seperti penyusutan alat pertanian, iuran subak, pajak lahan dan lain-lain biaya) sama dengan nul, karena tidak ada perbedaan biaya-biaya lain baik dalam nilai privat (finansial) maupun sosial (ekonomi).

Divergensi biaya lahan disebabkan oleh perbedaan nilai sewa lahan privat (finansial) jauh lebih rendah dari keuntungan yang mungkin dicapai seandainya lahan tersebut digunakan untuk usahatani komoditas kedelai. Besarnya selisih ini disebabkan oleh kurang berkembangnya sistem sewa lahan. Seperti apa yang ditemukan di lapangan, sedikit sekali petani yang menyewa maupun menyewakan lahannya.

Keuntungan privat (finansial) pada usahatani padi sawah adalah sebesar $\mathrm{Rp}$
8.343.248,82 per hektar sementara keuntungan sosialnya (ekonomi) adalah sebesar Rp 11.373.037,50 per hektar. Kedua nilai ini menimbulkan divergensi keuntungan bersih (net profit) yang negatif sebesar - Rp 3.029.788,68 per hektar, itu berarti bahwa kebijakan insentif yang ada belum membuat usahatani padi sawah efisien.

\section{Tingkat proteksi}

Kebijakan pemerintah dalam analisis PAM dapat pula dilihat melalui rasio antara nilai pada baris pertama (harga privat) dengan nilai pada baris kedua (harga sosial). Rasio lebih sering digunakan karena bisa digunakan untuk membandingkan berbagai sistem usahatani dengan output yang berbeda.

Rasio PAM untuk menduga adanya distorsi kebijakan dan atau tingkat proteksi pada usahatani padi sawah di Kabupaten Badungdisajikan pada Tabel 3.5. 
Tabel 5 Rasio PAM Usahatani Padi Sawah di Kabupaten Badung Pada Masa Tanam. 2014/2015

\begin{tabular}{|c|l|c|}
\hline No. & \multicolumn{1}{|c|}{ Rasio } & Nilai \\
\hline 1. & NPCO (Nominal Protection Coefficient on Output) & 0,76 \\
\hline 2. & NPCI (Nominal Protection Coefficient on Input) & 0,83 \\
\hline 3. & EPC (Effective Protection Coefficient) & 0,76 \\
\hline 4. & PC (Profitability Coefficient) & 0,73 \\
\hline 5. & SRP (Subsidy Ratio to Producers) & $-0,09$ \\
\hline
\end{tabular}

Sumber: Data primer.

\section{Dampak kebijakan output}

Rasio yang digunakan untuk mengukur divergensi dalam penerimaan (output transfers) disebut Nominal Protection Coefficient on Output (NPCO). Nilai NPCO usahatani padi sawah di Kabupaten Badung adalah 0,76. Nilai ini menunjukkan bahwa petani menerima harga privat $24 \%$ lebih rendah dari harga paritas impor (harga dunia). Dapat dikatakan bahwa petani di Kabupaten Badung dalam melakukan usahatani padi sawah belum menikmati subsidi output dari pemerintah.

Jika komoditas beras/padi merupakan komoditas ekspor, maka nilai NPCO yang lebih kecil dari satu sebenarnya dapat memacu ekspor. Hal ini disebabkan karena harga beras di pasar internasional yang lebih tinggi daripada harga beras di dalam negeri. Melemahnya nilai tukar rupiah terhadap dollar Amerika pada periode penelitian ini menyebabkan perbedaan harga output, antara harga output finansial dengan harga output ekonomi. Melemahnya nilai tukar rupiah terhadap dollar Amerika tersebut telah membebankan produsen dalam negeri.

Untuk melindungi produsen (petani) diperlukan suatu kebijakan yang dapat memacu peningkatan produksi baik kuantitas maupun kualitas beras dan merangsang kegiatan ekspor.

\section{Dampak kebijakan input}

Rasio yang digunakan untuk mengukur divergensi input tradabel (input transfers) disebut Nominal Protection Coefficient on Input (NPCI). Nilai NPCI untuk usahatani padi sawah di Kabupaten Badung adalah 0,83 . Nilai NPCI yang lebih kecil dari satu menunjukkan bahwa terdapat proteksi terhadap produsen input tradabel, sedangkan sektor yang menggunakan input tersebut yaitu produsen (petani) pelaku usahatani padi diuntungkan dengan rendahnya harga input tradabel. Itu berarti petani membayar 17\% lebih murah dari harga sosialnya. Murahnya input tradabel tersebut disebabkan oleh subsidi dari pemerintah berupa benih dan pupuk urea, serta adanya pengenaan tarif impor dan pajak pertambahan nilai terhadap pupuk lain, pestisida dan herbisida (sampai 20\%). Seperti diketahui bahwa pemerintah secara bertahap telah melakukan deregulasi dalam bentuk pengurangan tarif bea masuk (impor) produk pertanian dan pencabutan subsidi pupuk, namun masih terdapat kebijakan 
pemerintah atau distorsi pasar pada input tradabel yang menguntungkan produsen (petani) pelaku usahatani padi sawah dan merugikan produsen input tradabel karena membuat harga input tradabel yang dibayar produsen (petani) menjadi lebih murah dibanding tidak ada kebijakan atau distorsi pasar.

\section{Transfer gabungan}

Effective Protection Coefficient (EPC) menunjukkan dampak gabungan policy tranfers dari input dan output tradabel. EPC adalah rasio nilai tambah dalam nilai finansial dengan nilai tambah dalam nilai ekonomi. Nilai EPC menggambarkan sejauh mana seluruh kebijakan pemerintah yang ada bersifat melindungi atau menghambat suatu sistem komoditas. Dengan demikian besarnya proteksi efektif yang dinikmati petani sangat tergantung dari kombinasi transfer output dan transfer input.

Pada Tabel 3.5 nilai EPC usahatani padi sawah tersebut lebih kecil dari satu, yaitu sebesar 0,76 . Nilai ini menunjukkan bahwa secara keseluruhan, baik petani maupun sistem komoditas di Kabupaten Badung mengalami disproteksi sebesar $24 \%$. Itu berarti adanya kebijakan terhadap output dan input secara keseluruhan merugikan petani dan sistem komoditas, karena nilai tambah dalam nilai finansial lebih kecil dari nilai tambah dalam nilai sosial. Rendahnya proteksi efektif yang diterima petani pada usahatani padi sawah pada masa tanam 2014/2015 atau musim hujan tersebut dikarenakan selain petani membayar input tradabel 17\% lebih murah dari harga sosialnya, juga petani menerima harga output (privat) sebesar 24\% lebih rendah dari harga yang seharusnya (paritas impor atau harga internasional).

\section{Transfer bersih}

Net tranfers merupakan inti dari hasil sebuah analisis PAM. Nilai ratio yang berhubungan dengan net transfer adalah Profitability Coefficient (PC). PC mengukur dampak seluruh transfer terhadap keuntungan privat, dengan perkataan lain nilai PC merupakan ukuran relatif transfer bersih yang mengakibatkan keuntungan finansial lebih besar atau lebih kecil dari keuntungan ekonomi. PC juga merupakan pengembangan dari EPC dengan memasukkan biaya faktor domestik. Nilai PC untuk usahatani padi sawah di Kabupaten Badung adalah 0,73. Nilai ini menunjukkan keuntungan privat (finansial) yang jauh lebih besar, yaitu lebih dari 0,73 kali lipat dari keuntungan sosial (ekonomis). Berdasarkan nilai PC ini dapat dikatakan bahwa secara keseluruhan berbagai kebijakan pemerintah yang diterapkan pada sistem komoditas padi sawah mengakibatkan keuntungan (surplus) bertambah.

\section{Subsidy Ratio to Producers (SRP)} adalah ukuran dari gabungan seluruh transfer effects yang terjadi. Ratio ini merupakan perbandingan antara nilai net transfer dengan nilai output (penerimaan) yang dihitung pada tingkat harga dunia (penerimaan sosial atau social revenue). Dengan demikian SRP menunjukkan sejauh mana penerimaan (revenue) meningkat atau 
menurun karena terjadinya transfer. Nilai SRP usahatani padi sawah sebesar - 0,09. Artinya, divergensi antara keuntungan finansial dan ekonomi pada usahatani padi sawah sekitar - 9\% dari pendapatan kotor (gross profit). Besarnya transfer negatif (negative transfers) di atas menunjukkan bahwa secara umum kebijakan pemerintah atau distorsi pasar yang ada memberikan dampak yang merugikan bagi petani padi sawah, karena petani padi sawah menerima subsidi negatif dibandingkan jika tidak ada kebijakan pemerintah.

\section{Analisis Titik Impas Harga Ekonomi}

Usahatani padi sawah di Kabupaten Badung akan mencapai titik impas, yaitu pada keuntungan ekonomi nul, ketika harga gabah internasional pada usahatani padi sawah pada masa tanam 2014/2015 sebesar Rp 3.290,41/kg. Analisis titik impas selengkapnya seperti pada Tabel 3.6 berikut.

Tabel 6 Analisis Titik Impas Harga Ekonomi Usahatani Padi Sawah di Kabupaten Badung Masa Tanam 2014/2015

\begin{tabular}{lr}
\hline \multicolumn{1}{c}{ Uraian } & \multicolumn{1}{c}{ Padi Sawah } \\
& MT 2014/2015 \\
\hline Produksi (kg/ha) & $6.854,43$ \\
Total biaya ekonomi (Rp/ha) & $22.553 .893,24$ \\
Harga ekonomi (Rp/kg) & $3.290,41$ \\
\hline Sumber: Data primer. &
\end{tabular}

Sedangkan harga gabah secara ekonomi yang diterima petani selama periode penelitian pada usahatani padi sawah adalah Rp 4.949,63/kg lebih tinggi dari titik impas. Tingginya harga ekonomi ini, mencerminkan risk premium yang ditanggung oleh importir beras jauh di atas titik impas dan menunjukkan tingginya keuntungan ekonomi yang diterima petani.

\section{Analisis Sensitivitas}

Beberapa kondisi yang mungkin terjadi dalam jangka pendek dan bersifat tidak menguntungkan adalah sebagai berikut:

(1) Nilai rupiah akan semakin melemah (depresiasi) terhadap dollar Amerika Serikat menjadi Rp 13.500 per US \$ dan nilai rupiah akan menguat (apresiasi) menjadi Rp 11.900,00 per US \$ sesuai asumsi dasar ekonomi makro Tahun 2015 .

(2) Meningkatnya subsidi output yang setara dengan harga bayangan, yaitu sebesar Rp 4.949,63/kilogram gabah kering panen.

(3) Adanya subsidi benih padi sebesar Rp 5.500,00/kilogram, benih kedelai sebesar Rp 10.000,00/kilogram, subsidi ganda pupuk NPK Phonska sebesar Rp $8.00,00 / \mathrm{kg}$ dan pupuk organik sebesar Rp 400,00/kg dari kegiatan APBD Kabupaten Badung.

(4) Ada kecenderungan bahwa produktivitas gabah semakin berkurang karena penggunaan benih berkualitas bukan F1 (generasi pertama) tetapi turunannya, dan adanya serangan hebat 
hama/penyakit. Kalau teknologi produksi tidak berkembang, hasil gabah akan berkurang sampai 20 persen. Kasus ini bisa saja dijumpai di beberapa daerah produksi seperti di Kabupaten Badung, yang menyebabkan petani menderita kerugian.

Nilai tukar merupakan salah satu komponen ekonomi makro yang sangat luas pengaruhnya dalam perdagangan internasional. Nilai tukar yang dipakai untuk menganalisis sensitivitas usahatani padi sawah adalah nilai tukar aktual. Pemerintah selalu mempengaruhi nilai tukar melalui kebijakan moneter untuk menjaga stabilitas nilai tukar rupiah terhadap US \$ dengan melepas cadangan devisa melalui Bank Indonesia.

Melemahnya nilai tukar rupiah (depresiasi) dari Rp 12.775,35/US\$ menjadi Rp 13.500,00/US\$ secara analisis akan semakin meningkatkan daya saing pada nilai ekonomis (keunggulan komparatif) dari usahatani padi sawah di Kabupaten Badung, karena nilai DRC cenderung menurun menjadi 0,64 bahkan tidak menurunkan daya saing pada nilai finansial (keunggulan kompetitif)karena nilai PCR tidak mengalami perubahan. Namun dari subsidi output yang diberikan pemerintah, petani padi akan semakin teraniaya karena nilai NPCO menjadi 0,74sehingga mengakibatkan petani menerima harga privat $26 \%$ lebih rendah dari harga paritas impor (harga dunia). Dapat dikatakan bahwa petani di Kabupaten Badung dalam melakukan usahatani padi sawah masih belum menikmati subsidi output dari pemerintah. Sebaliknya dari subsidi Input terdapat proteksi terhadap produsen input tradabel dan petani sebagai pelaku utama usahatani padi diuntungkan dengan rendahnya harga input tradabelhingga 20\% lebih murah dari harga sosialnya.

Melemahnya nilai tukar rupiah juga berdampak terhadap transfer gabungan dari input dan output tradabel (EPC), tingkat keuntungan privat atas tingkat keuntungan sosial (PC) dan transfer effects (SRP) yang cenderung mengalami penurunan. Nilai EPC turun menjadi 0,73 itu berarti bahwa dengan melemahnya nilai tukar rupiah (depresiasi) dari Rp 12.775,35/US\$ menjadi Rp 13.500,00/US\$ baik petani maupun sistem komoditas di Kabupaten Badung semakin tidak terproteksi (semakin mengalami kerugian dimana nilai tambah dalam nilai finansial semakin berkurang dari nilai tambah dalam nilai sosial) sebesar $27 \%$. Sedangkan nilai PC sebesar 0,69 menunjukkan bahwa keuntungan privat (finansial) atas keuntungan ekonomis masih sebesar 0,69 kali lipat. Secara keseluruhan transfer effects yang terjadi masih bernilai negatif sebesar $\quad-\quad 0,11 \quad$ yang mengindikasikan bahwa secara umum kebijakan pemerintah atau distorsi pasar yang ada masih memberikan dampak yang merugikan bagi petani padi sawah. Besarnya divergensi antara keuntungan finansial dan ekonomi pada usahatani padi sawah sekitar - $11 \%$ dari pendapatan kotor (gross profit).

Sebaliknya menguatnya nilai tukar rupiah (apresiasi) dari Rp 12.775,35/US\$ 
menjadi Rp 11.900,00/US\$ belum menunjukkan kehilangan daya saing pada nilai finansial (keunggulan kompetitif) dan pada nilai ekonomis (keunggulan komparatif) atau petani dan sistim komoditas padi sawah masih diuntungkan, namun terdapat kecenderungan bahwa menguatnya nilai tukar rupiah akan melemahkan daya saing pada nilai ekonomisnya (keunggulan komparatif). Hal ini dikarenakan nilai DRC semakin meningkat (nilai DRC menjadi 0,66).

Menguatnya nilai rupiah terhadap dollar Amerika (US\$) juga akan meningkatkan nilai NPCO, NPCI, EPC, PC dan SRP usahatani padi sawah di Kabupaten Badung. Namun penguatan nilai tukar sebesar Rp 11.900,00/US\$ ini masih belum memproteksi petani atau petani belum menerima insentif dari pemerintah.

Dari hasil analisis di atas tampak bahwa betapa sensitifnya usahatani padi sawah terhadap perubahan nilai tukar. Keunggulan komparatif menurun secara proporsional ketika rupiah terapresiasi, begitu sebaliknya keunggulan komparatif meningkat secara proporsional ketika rupiah terdepresiasi. Tetapi semakin menguatnya nilai tukar rupiah maka semakin besar kemungkinan petani untuk memperoleh insentif (proteksi) pemerintah.

Hasil analisis sensitivitas usahatani padi sawah di Kabupaten Badung pada nilai tukar Rp 11.900,00/\$US dan Rp $13.500,00 / \$$ US selengkapnya disajikan pada Tabel 3.7.

Meningkatnya subsidi output yang setara dengan harga bayangan, yaitu sebesar Rp 4.949,63/kilogram gabah kering panen, menunjukkan bahwa pada kondisi ini usahatani padi sawah di Kabupaten Badung akan terjadi peningkatan nilai NPCO, EPC, PC dan SRP sedangkan nilai NPCI dan DRC tidak berubah (tetap) bahkan nilai PCR turun menjadi 0,58. Keadaan ini menunjukkan bahwa usahatani padi sawah di Kabupaten Badung tetap memiliki daya saing pada nilai finansial dan ekonomis (PCR dan DRC $<1$ ), bahkan usahatani padi sawah akan semakin kompetitif dibandingkan sebelumnya. karenadapat menurunkan nilai PCR. 
Tabel 7 Analisis Sensitivitas Usahatani Padi Sawah Pada Nilai Tukar Rp 11.900,00/\$USdan Rp 13.500,00/\$US di Kabupaten Badung

\begin{tabular}{|l|c|c|c|}
\hline \multirow{2}{*}{ Rasio } & \multirow{2}{*}{ Nilai Basis } & \multicolumn{2}{c|}{ Nilai Tukar } \\
\cline { 3 - 4 } & & Rp 11.900,00/\$US & Rp 13.500,00/SUS \\
\hline NPCO & 0,76 & 0,80 & 0,74 \\
NPCI & 0,83 & 0,87 & 0,80 \\
PCR & 0,66 & 0,66 & 0,66 \\
DRC & 0,65 & 0,66 & 0,64 \\
EPC & 0,76 & 0,80 & 0,73 \\
PC & 0,73 & 0,80 & 0,69 \\
SRP & $-0,09$ & $-0,07$ & $-0,11$ \\
\hline
\end{tabular}

Sumber: Data primer

Meningkatnya subsidi output yang setara dengan harga bayangan, yaitu sebesar Rp 4.949,63/kilogram gabah kering panen memberi dampak pada semakin meningkatnya manfaat (keuntungan) dari kebijakan subsidi output karena petani menerima harga output yang sesuai dengan harga bayangan/sosialnya. Selain itu dapat meningkatkan nilai proteksi efektif, tingkat keuntungan privat atas tingkat keuntungan sosial dan transfer effects bagi petani secara positif, dengan demikian petani masih menerima subsidi positif dibandingkan jika tidak ada kebijakan pemerintah. Bahkan petani sebagai konsumen input tradabel masih tetap menerima manfaat dari kebijakan input sebesar 17\%, dengan perkataan lain petani sebagai konsumen input tradabel membayar 17\% lebih murah dari harga sosialnya dan murahnya input tradabel tersebut disebabkan oleh subsidi dari pemerintah. Hasil analisis sensitivitas usahatani padi sawah akibat subsidi output yang setara dengan harga bayangan disajikan pada Tabel 3.8.
Kebijakan subsidi ganda dari program APBD Kabupaten Badung terhadap input tradabel seperti Benih Padi, Benih Kedelai, Pupuk NPK Phonska dan Pupuk Organik akan menurunkan nilai NPCI hingga menjadi 0,67. Itu berarti produsen input tradabel menerima proteksi dari pemerintah, sedangkan sektor yang menggunakan input tersebut yaitu produsen (petani) pelaku usahatani padi diuntungkan dengan rendahnya harga input tradabel. Besarnya keuntungan yang dirasakan oleh petani adalah sebesar $33 \%$ dimana petani membayar lebih murah dari harga sosialnya yang disebabkan oleh subsidi ganda dari Pemerintah Kabupaten Badung.

Program subsidi ganda Pemerintah Kabupaten Badung terhadap input tradabel seperti benih dan pupuk ternyata tidak mempengaruhi daya saing usahatani padi sawah pada nilai ekonomi, bahkan dapat meningkatkan daya saing pada nilai finansial karena nilai PCR turun menjadi 0,65 . 
Tabel 8 Analisis Sensitivitas Usahatani Padi Sawah Pada Harga Output Setara Dengan Harga Bayangandi Kabupaten Badung

\begin{tabular}{|l|c|c|}
\hline \multicolumn{1}{|c|}{ Rasio } & Nilai Basis & $\begin{array}{c}\text { Harga Output Setara Dengan } \\
\text { Harga Bayangan }\end{array}$ \\
\hline NPCO & 0,76 & 1,00 \\
NPCI & 0,83 & 0,83 \\
PCR & 0,66 & 0,58 \\
DRC & 0,65 & 0,65 \\
EPC & 0,76 & 1,01 \\
PC & 0,73 & 1,21 \\
SRP & $-0,09$ & 0,07 \\
\hline
\end{tabular}

Sumber: Data primer

Namun berdasarkan dampak gabungan komoditas dibandingkan tanpa adanya policy tranfers dari input dan output tradabel kebijakan. Hasil analisis sensitivitas (EPC), tingkat keuntungan privat atas usahatani padi sawah atas subsidi ganda tingkat keuntungan sosial (PC) dan transfer Pemerintah Kabupaten Badung effects (SRP) cenderung mengalami selengkapnya disajikan pada Tabel 3.9. peningkatan yang mengarah kepada perbaikan perlindungan petani dan sistem

Tabel 9 Analisis Sensitivitas Usahatani Padi Sawah AtasProgram Subsidi Ganda Pemerintah Kabupaten Badung.

\begin{tabular}{|l|c|c|}
\hline \multicolumn{1}{|c|}{ Rasio } & Nilai Basis & Subsidi Ganda \\
\hline NPCO & 0,76 & 0,76 \\
NPCI & 0,83 & 0,67 \\
PCR & 0,66 & 0,65 \\
DRC & 0,65 & 0,65 \\
EPC & 0,76 & 0,77 \\
PC & 0,73 & 0,77 \\
SRP & $-0,09$ & $-0,08$ \\
\hline
\end{tabular}

Sumber: Data primer 
Penurunan produktivitas gabah sebesar $20 \%$ atau produktivitas menjadi $5.483,544$ $\mathrm{kg} / \mathrm{ha}$ menyebabkan keuntungan finansial (privat) dan ekonomis (sosial) akan turun. Tetapi hasil analisis menunjukkan bahwa terjadi perubahan rasio PAM dimana nilai PCR, DRC, PC dan SRP mengalami peningkatan. Meningkatnya nilai PCR dan DRC masing-masing menjadi 0,75 dan 0,82 menunjukkan bahwa usahatani padi sawah di Kabupaten Badung masih tetap memiliki daya saing pada nilai finansial (keunggulan kompetitif) dan daya saing pada nilai ekonomis (keunggulan komparatif) karena nilai $\mathrm{PCR}$ dan $\mathrm{DRC}<1$. Namun tingkat daya saing pada nilai finansial (keunggulan kompetitif) dan daya saing pada nilai ekonomis (keunggulan komparatif) semakin berkurang dibandingkan sebelumnya. Dengan perkataan lain penurunan produktivitas gabah sebesar $20 \%$ akan membuat usahatani padi sawah mengalami pelemahan daya saing pada nilai finansial (keunggulan kompetitif) dan daya saing pada nilai ekonomis (keunggulan komparatif). Kebijakan subsidi output, subsidi input dan transfer gabungan dari input dan output tradabel (EPC) terhadap petani dan sistem komoditas tidak mengalami perubahan akibat penurunan produktivitas gabah sebesar $20 \%$.Sebaliknya meningkatnya nilai PC menjadi 1,05 menunjukkan bahwa terdapat keuntungan privat (finansial) yang lebih besar atau meningkat sebesar 1,05 kali lipat dari keuntungan ekonomis. Namun secara keseluruhan dari transfer effects yang terjadi, maka dampak kebijakan pemerintah dan distorsi pasar yang ada memberikan dampak yang menguntungkan bagi petani, karena petani masih menerima subsidi positif dibandingkan jika tidak ada kebijakan pemerintah dimana nilai SRP meningkat menjadi 0,01 . Hasil analisis sensitivitas usahatani padi jika produktivitas turun sebesar $20 \%$ di Kabupaten Badung disajikan pada Tabel 3.10.

Tabel 10 Analisis Sensitivitas Usahatani Padi Sawah Jika Produktivitas Turun 20 Persen di Kabupaten Badung.

\begin{tabular}{|l|c|c|}
\hline \multicolumn{1}{|c|}{ Rasio } & Nilai Basis & $\begin{array}{c}\text { Produktivitas } \\
\text { Turun 20 Persen }\end{array}$ \\
\hline NPCO & 0,76 & 0,76 \\
NPCI & 0,83 & 0,83 \\
PCR & 0,66 & 0,75 \\
DRC & 0,65 & 0,82 \\
EPC & 0,76 & 0,76 \\
PC & 0,73 & 1,05 \\
SRP & $-0,09$ & 0,01 \\
\hline
\end{tabular}

Sumber: Data primer. 


\section{SIMPULAN DAN SARAN}

\section{Simpulan}

Usahatani padi sawah di Kabupaten Badung masih memiliki daya saing baik pada nilai finansial (keunggulan kompetitif) maupun nilai ekonomis (keunggulan komparatif), karena besarnya rasio biaya privat (PCR) dan rasio sumberdaya domestik (DRC) yang ditimbulkan akibat depresiasi rupiah lebih kecil dari satu, masing-masing 0,66 dan 0,65.

Dampak depresiasi rupiah terhadap kebijakan pemerintah berkenaan dengan tingkat proteksi usahatani padi di Kabupaten Badung adalah sebagai berikut:

a. Petani di Kabupaten Badung dalam melakukan usahatani padi sawah belum menikmati subsidi output dari pemerintah. Divergensi penerimaan bernilai negatif (- Rp 7.983.946,00 per hektar) dan nilai NPCO adalah 0,76 menunjukkan bahwa petani menerima harga privat $24 \%$ lebih rendah dari harga paritas impor (harga dunia).

b. Kebijakan subsidi input dari pemerintah menguntungkan produsen input tradabel dan petani. Divergensi input yang diperdagangkan (tradable inputs) bernilai negatif (- Rp 297.598,89 per hektar) dan nilai NPCI yang dihasilkan 0,83 menunjukkan bahwa petani membayar input tradabel $17 \%$ lebih murah dari harga sosialnya c. Kebijakan subsidi juga terjadi pada faktor domestik. Divergensi faktor domestik pada usahatani padi sawah bernilai negatif menunjukkan adanya kebijakan subsidi dari pemerintah.

d. Kebijakan insentif yang ada ternyata belum membuat usahatani padi sawah efisien, hal ini ditunjukkan dengan divergensi keuntungan bersih (net profit) usahatani padi sawah di Kabupaten Badung bernilai negatif.

e. Kebijakan output dan input secara keseluruhan merugikan petani dan sistem komoditas, karena memberikan nilai tambah dalam nilai finansial lebih kecil dari nilai tambah dalam nilai sosial. Nilai EPC usahatani padi sawah 0,76 menunjukkan bahwa secara keseluruhan, baik petani maupun sistem komoditas di Kabupaten Badung mengalami disproteksi sebesar $24 \%$.

f. Tingkat keuntungan privat atas tingkat keuntungan sosial (PC) adalah $\quad 0,73 \quad$ sehingga mengakibatkan keuntungan privat (finansial) bertambah, yaitu lebih dari 0,73 kali lipat dari keuntungan sosial (ekonomis).

g. Divergensi antara keuntungan finansial dan ekonomi pada usahatani padi sawah sekitar - 9\% dari pendapatan kotor (gross profit). Besarnya transfer negatif (negative 
transfers/nilai SRP $=-0,09)$, menunjukkan bahwa secara umum kebijakan pemerintah atau distorsi pasar yang ada memberikan dampak yang merugikan bagi petani padi sawah, karena petani padi sawah menerima subsidi negatif dibandingkan jika tidak ada kebijakan pemerintah.

\section{Implikasi Kebijakan}

Usahatani padi sawah di Kabupaten Badung akan mencapai titik impas, ketika harga gabah kering panen internasional sebesar Rp 3.290,41/kg. Sedangkan harga gabah kering panen internasional yang diterima petani pada periode penelitian adalah sebesar Rp 4.949,63/kg lebih tinggi dari titik impas. Tingginya harga gabah kering panen internasional ini, mencerminkan adanya risk premium yang ditanggung oleh importir jauh di atas titik impas dan menunjukkan tingginya keuntungan ekonomi yang diterima petani padi.

Usahatani padi sawah sangat sensitifnya terhadap perubahan nilai tukar. Keunggulan komparatif meningkat secara proporsional ketika rupiah terdepresiasi begitu sebaliknya keunggulan komparatif menurun secara proporsional ketika rupiah terapresiasi. Tetapi semakin menguatnya nilai tukar rupiah maka semakin besar kemungkinan petani untuk memperoleh insentif (proteksi) dari pemerintah.

Jika subsidi output ditingkatkan dan setara dengan harga bayangan, yaitu sebesar Rp 4.949,63/kg gabah kering panen, maka pada keadaan ini usahatani padi sawah di Kabupaten Badung tetap memiliki daya saing pada nilai finansial dan ekonomis (PCR dan DRC $<1$ ), bahkan usahatani padi sawah akan semakin kompetitif dan masih tetap menerima manfaat dari kebijakan input, output, proteksi efektif, tingkat keuntungan privat atas tingkat keuntungan sosial dan transfer effects bagi petani secara positif.

Program subsidi ganda dari Pemerintah Daerah Kabupaten Badung terhadap input tradabel seperti benih dan pupuk ternyata tidak mempengaruhi daya saing usahatani padi sawah pada nilai ekonomi, bahkan dapat meningkatkan daya saing pada nilai finansial, produsen input tradabel dan petani menerima proteksi dari pemerintah, dampak gabungan policy tranfers dari input dan output tradabel (EPC), tingkat keuntungan privat atas tingkat keuntungan sosial (PC) dan transfer effects (SRP) cenderung mengalami peningkatan yang mengarah kepada perbaikan perlindungan petani dan sistem komoditas dibandingkan tanpa adanya kebijakan.

Jika produktivitas gabah turun sebesar $20 \%$, maka pada kondisi ini usahatani padi sawah di Kabupaten Badung masih tetap memiliki daya saing pada nilai finansial (keunggulan kompetitif) dan daya saing pada nilai ekonomis (keunggulan komparatif) karena nilai PCR dan DRC $<1$. Namun tingkat daya saing pada nilai finansial (keunggulan kompetitif) dan daya saing pada nilai ekonomis (keunggulan komparatif) semakin berkurang atau 
semakin melemah dibandingkan sebelumnya. Bahkan terdapat tingkat keuntungan privat (finansial) yang lebih besar atau meningkat sebesar 1,05 kali lipat dari tingkat keuntungan ekonomis dan cenderung meningkatkan nilai keseluruhan dari transfer effects.

\section{Saran}

Oleh karena usahatani padi sawah sangat dipengaruhi oleh perkembangan ekonomi makro, maka setiap perubahan terhadap nilai tukar, suku bunga, inflasi dan kebijakan perdagangan internasional juga dapat berdampak pada sistem usahatani. Depresiasi rupiah memang dapat meningkatkan keunggulan komparatif namun disisi lain menurunkan tingkat proteksi usahatani secara keseluruhan. Usaha terbaik dari pemerintah adalah mengupayakan untuk menguatkan nilai tukar rupiah, karena semakin menguatnya nilai tukar rupiah maka semakin besar kemungkinan petani untuk memperoleh insentif (proteksi) dari pemerintah.

Hasil analisis menunjukkan bahwa usahatani padi sawah di Kabupaten Badung layak untuk terus dikembangkan dan memiliki daya saing baik dalam nilai finansial maupun ekonomi, namun dalam penelitian ini adanya kebijakan output dan input secara keseluruhan masih merugikan petani dan sistem komoditas. Kebijakan output sebagai dampak depresiasi rupiah saat ini ternyata masih belum mensejahterakan petani, maka kebijakan yang mendesak dan berpihak kepada petani dan konsumen adalah meningkatkan subsidi output yang setara dengan harga bayangannya yaitu sebesar Rp 4.949,63/kg gabah kering panen.

\section{DAFTAR PUSTAKA}

Badan Pusat Statistik, 2014. Konsumsi Rata-Rata per Kapita Seminggu Beberapa Macam Bahan Makanan Penting. [online] Tersedia pada http://www.bps.go.id/linkTabelStatis/vi ew/id/950 [Diakses pada 15 Maret 2015].

Badan Pusat Statistik, 2015.Luas Panen, Produktivitas dan Produksi Tanaman Pangan menurut Provinsi Tahun 2014. [online] Tersedia pada $<\underline{\text { http://www.bps.go.id/Subjek/view/id/ }}$ 53> [Diakses pada 5 April 2015].

Dinas Pertanian Perkebunan dan Kehutanan Kabupaten Badung, 2014. Penyediaan dan Kebutuhan Beras di Kabupaten Badung Tahun 2007 - 2014. Dinas Pertanian Perkebunan dan Kehutanan Kabupaten Badung.

Kementerian Pertanian RI, 2014. Data Lima Tahun Terakhir, Sektor Tanaman Pangan. [online] Tersedia pada $<$ http://www.pertanian.go.id/ap_pages/ $\underline{\mathrm{mod} / \text { dataterkini }>}$ [Diakses pada 16 Februari 2015].

Kardinan, A., 2011. Penggunaan pestisida nabati sebagai kearifan lokal dalam pengendalian hama tanaman menuju sistem pertanian organik.Pengembangan Inovasi Pertanian, 4 (4), artikel 1.

Kementerian Pertanian RI, 2015. Rencana Strategis 2015 - 2019. [online] Tersedia pada $<$ http://www.pertanian.go.id/file/RENS TRA_2015-2019.pdf> [Diakses pada 10 Oktober 2015].

Kompas, 2011. Mentan: Umumkan Data Beras yang Baru. [online] Tersedia pada

$<$ http://bisniskeuangan.kompas.com/rea d/2011/09/19/14342011/mentan.umum kan.data.beras.yang.baru> [Diakses pada 8 Februari 2015].

Kompas, 2012. Konsumsi Beras Indonesia Tertinggi di Asia Tenggara. [online] Tersedia pada $<$ http://bisniskeuangan.kompas.com/rea 
d/2012/02/07/21065277/Konsumsi.Ber as.Indonesia.Tertinggi.di.Asia.Tenggar a $>$ [Diakses pada 10 Februari 2015].

Pearson, S., Gotsch, C., dan Bahri, S., (2005). Aplikasi policy analysis matrix pada pertanian Indonesia. Yayasan Obor Indonesia, Jakarta (ID).

Saptana, 2009.Keunggulan KomparatifKompetitif dan Strategi Kemitraan. Pusat Penelitian dan Pengembangan Sosial Ekonomi Pertanian. Badan Litbang Pertanian. Departemen Pertanian RI. Jakarta.

Sudaryanto, T. dan Rachman, B., 2000. Arah Kebijakan Distribusi/Perdagangan Beras dalam Mendukung Ketahanan Pangan dan Hortikultura. Ditjen Tanaman Pangan dan Hortikultura, Departemen Pertanian.
Timmer, C. P., Falcon, W. P., Pearson, S. R., and World Bank,(1983). Agriculture and Rural Development. Food policy analysis Vol. 1983, pp. 1301.

Zaini, Z. (2009). Memacu peningkatan produktivitas padi sawah melalui inovasi teknologi budi daya spesifik lokasi dalam era revolusi hijau lestari. Pengembangan Inovasi Pertanian, 2(1), 35-47. 
